\title{
Pharmacovigilance Activities in the Treatment of COVID-19
}

\author{
COVID-19 Tedavisinde Farmakovijilans Aktiviteleri
}

Ozal, Gizem ${ }^{1}$

Orcid: 0000-0003-1928-566X,

Inceoglu, Bilge ${ }^{1}$

Orcid: 0000-0003-1172-1711,

Suzgec, Sezen ${ }^{1}$

Orcid: 0000-0001-5865-8110,

Duran, Nur Hilal ${ }^{1}$

Orcid: 0000-0001-7160-4408,

Topaloglu, Gizem

Orcid:0000-0003-0580-5337,

Arda, Burcu Eda ${ }^{1}$

Orcid: 0000-0002-6767-9092,

Erkoc, Gozdenur ${ }^{1}$

Orcid: 0000-0001-6315-8807,

Gulhan, $\mathrm{Ali}^{1}$

Orcid: 0000-0001-7460-0576

${ }^{1}$ Excelya Medikal Araştırma ve Danışmanlık AŞ, Department of Pharmacovigilance and Safety, Istanbul, Turkey

Corresponding author:

Burcu Eda Arda

Excelya Medikal Araştırma ve Danışmanlık AŞ, Department of Pharmacovigilance and Safety, İstanbul

E-mail: burcuedaarda@hotmail.com https://orcid.org/0000-0002-6767-9092

\begin{abstract}
The unexpected pandemic initiated by the new coronavirus 2019 (2019-nCoV) caused severe panic among people around the world since December 2019. Coronavirus disease 2019 (COVID-19) has wreaked havoc, and Health Authorities have started to make announcements and studies have been started quickly, for effective treatment and vaccination. In studies, drugs that reduce the symptoms of COVID-19 and alleviate the course of the disease have been used. In addition to the effects of these promising drugs, adverse events and multiple drug interactions have begun to appear all over the world, as well as in our country. Therefore, pharmacovigilance is of particular importance during the COVID-19 pandemic. Health authorities have been taking additional actions and measures to carry out adverse effects monitoring and risk minimization activities of drugs. In our study, we have reviewed the measures taken related to COVID-19 in Turkey and around the world along with safety of drugs used to treat COVID-19 and pharmacovigilance activities during the pandemic.
\end{abstract}

Keywords: SARS-CoV-2, COVID-19, Pharmacovigilance, Drug Safety, Adverse Event

\section{ÖZET}

Aralık 2019'dan bu yana yeni tip koronavirüsün (2019-nCoV) başlattığı beklenmedik pandemi, dünyanın dört bir yanındaki insanlar arasında şiddetli paniğe neden olmuştur. Koronavirüs hastalığı 2019 (COVID-19) ciddi hasarlara yol açmış ve Sağlı otoriteleri tarafından yayınlanan duyurular ile etkili tedavi ve aşı için çalışmalara hızlıca başlanmıştır. Çalışmalarda, COVID-19 semptomlarını azaltıcı ve hastalığın seyrini hafifletici ilaçlar kulanılmaya başlanmıştır. Umut vadeden bu ilaçların etkilerinin yanısıra, tüm dünyada ve ülkemizde advers olaylar ve çoklu ilaç etkileşimleri görülmeye başlanmıştır. Bu nedenle, COVID-19 pandemi sürecinde farmakovijilans ayrı bir önem arz etmektedir. İlaçların advers etkilerinin takibi ve risk minimizasyon faaliyetlerini yürütmek açısından sağlık otoriteleri ek aksiyonlar ve önlemler almaktadır. Çalışmamızın amacı, Türkiye'de ve dünyada COVID-19 ile ilgili alınan önlemler ile birlikte, COVID-19 tedavisinde kullanılan ilaçların güvenliği ve pandemi sürecindeki farmakovijilans aktivitelerini derlemektir.

Anahtar Kelimeler: SARS-CoV-2, COVID-19, Farmakovijilans, İlaç Güvenliliği, Advers Olay 


\section{Introduction}

The pneumonia cases with unknown etiology started to be reported in Wuhan, Hubei Province, China in December 2019 [1]. The Chinese authorities identified a new type of coronavirus (2019-nCoV) which was not previously detected in humans on January 7th, 2020 [2]. The virus renamed as severe acute respiratory syndrome coronavirus 2 (SARS-CoV-2) due to its close similarity to SARS-CoV. Then, 2019nCoV disease was accepted as COVID-19 [1]. Coronaviruses are a fairly large family of viruses, with subtypes found in humans that can be transmitted from one person to another, often causing mild infection, such as the common cold. However, many coronavirus subtypes, detected in animals, can cause severe illness in humans when transmitted from animals to humans [1]. The viruses that caused the SARS-CoV outbreak in 2002 and the Middle East respiratory syndrome coronavirus (MERS-CoV) outbreak in 2012 also belong to the same family named Coronaviridae [3,5].

SARS-CoV-2, like other coronaviruses, is an enveloped, single-stranded RNA virus [6]. One of the structural protein types of the coronaviruses, spike (S) protein, is important for infection mechanism because of its assistance viral entry into the host cell by binding to angiotensin-converting enzyme 2 (ACE2) receptor $[7,8]$. SARS-CoV and SARS-CoV-2 are similar because they both use S protein and ACE2 as a receptor [3].

The spectrum of illness caused by COVID-19 in humans can range from the common cold (mild respiratory symptoms) to lethal symptoms which are associated with severe pneumonia, acute respiratory distress, and renal failure $[1,6]$. It can also cause enteric, hepatic, nephrotic and neurological involvement in humans [1]. The most frequent symptoms of COVID-19 infection are fever, dry cough, myalgia, fatigue, and dyspnea [1,7]. Additional symptoms can be seen as headache, sore throat, nasal discharge, loss of sense of smell and taste, and diarrhea [1]. Cases with severe symptoms and deaths are generally seen in elderly patients or patients with concomitant systemic diseases like hypertension, diabetes, cardiovascular disease, cancer, chronic lung diseases and other immunosuppressive conditions [1]. Even though symptoms are various, there is a chance that patients may be asymptomatic.

Due to the speed and severity of the virus, the pan- demic was declared on March 11, 2020, as it was already spread to 113 countries outside of China. The most important reason for COVID-19 to transform into a pandemic is the ease of its transmission. The ways of transmission are direct contact, indirect contact, aerosol and droplet [9].

As it did in all countries, coronavirus began to spread across Turkey. Ministry of Health announced the first case on March 11, 2020. According to the information reported by governments, 30,372,127 people were infected in the world and 949,486 of them died as of October 1st. In Turkey, 7,315 deaths were reported out of 298,039 cases, as of October 1st $[9,10]$.

\section{Pharmacovigilance Activities of Authorities During Covid-19 Pandemic}

Pharmacovigilance system has been greatly affected by the COVID-19 pandemic, like every part of the healthcare systems in the world. Health authorities have published various announcements about drug safety almost every day to ensure that pharmacovigilance processes are carried out correctly and completely. Regulatory authorities also play a very important role in pharmacovigilance during the COVID-19 pandemic.

WHO (World Health Organization) has published Solidarity Clinical Trial for COVID-19 Treatments [11].

EMA (European Medicines Agency) announced the first notification about COVID-19 entitled "Guidance for medicine developers and other stakeholders on COVID-19" on the 4th of February. More than a hundred announcements were shared during the 7-month pandemic period after the first notification. These announcements were related to guidance for medicine developers and other stakeholders, availability of medicines, treatments and vaccines and public-health advice. EMA has explained how to act on pharmacovigilance processes and inspections with the announcements it has published throughout the pandemic [12].

Meanwhile, FDA (U.S. Food \& Drug Administration) announced the first notification about COVID-19 on the 27th of January. According to this notification, FDA published key activities to the advancement of novel coronavirus medical countermeasures. The announcements are published almost 
every day to include recent information and updates on the COVID-19 pandemic [13].

The first announcement shared by ANSM (French Agency for the Safety of Health Products) about COVID-19 on the 3rd of March was related to mask stock demand [14]. A special system established by ANSM aimed to monitor drug-related adverse reactions more carefully. With this system, the focus was on the follow-up monitoring of drug-related adverse reactions, as well as medication errors and overdose cases [15].

In the UK, the situation regarding pharmacovigilance processes in pandemic started by MHRA (Medicines and Healthcare products Regulatory Agency) announcing the first notification about COVID-19 on the 22nd of January. MHRA explained the monitoring of the coronavirus situation in Wuhan. This notification was mainly related to travel restrictions [16]. Unlike Europe, MHRA has defined various flexible areas regarding regulatory processes. Some of these are about risk minimization measures, reporting requirements for ICSRs (Individual case safety reports), follow-up procedures, postponement of other pharmacovigilance requirements (Periodic safety update reports submission frequencies, submission dates etc.) [17].

During the COVID-19 pandemic, the International Council of Harmonization (ICH) Medical Dictionary for Regulatory Activities (MedDRA) Management Committee has announced that MedDRA Version 23.0 was updated urgently. Updates were published for the medical terminology dictionary MedDRA which is actively used in the processes related to pharmacovigilance. Some of the terms added during this period are COVID-19, COVID-19 respiratory infection, SARS-CoV-2 acute respiratory disease, SARS-CoV-2 infection, COVID-19 treatment, COVID-19 virus test false positive [18].

In this COVID-19 pandemic, while some authorities simplified regulatory processes, some authorities introduced new requirements for drug safety and pharmacovigilance. In any case, the common purpose of all authorities is to take their own precautions for the uninterrupted progress of pharmacovigilance processes, by publishing informative announcements.

\section{Pharmacological Therapies Considered For Treatment of Covid-19}

The unexpected epidemic initiated by COVID-19 has caused severe panic among people around the world, hence scientists and doctors have started drug and vaccine studies to treat COVID-19, whilst also testing the efficacy and safety of used drugs [19].

Drug development is a multi-step process and typically requires more than five years to ensure the safety and effectiveness of the new compound [20]. Several national regulatory agencies, such as EMA and FDA, approved procedures to expedite clinical testing $[21,22]$.

Currently, there is no proven effective treatment or vaccine against COVID-19 infection. Therefore, no standard therapy is available. A large number of drugs are used empirically based on experience and availability. Studies showing their effectiveness and safety are still being published [23].

During this pandemic, a variety of treatments have been clinically used as potential treatments against COVID-19 in severe cases and critically ill patients. These are approved treatments for non-COVID-19 indications such as nucleoside analogues ribavirin and favipiravir, antimalarial chloroquine/hydroxychloroquine, antiviral combination lopinavir/ritonavir, pegylated interferon alpha-2a and $-2 b$ as well as the experimental drug remdesivir. Globally, several randomized clinical trials are currently underway to evaluate the efficacy and safety of potential treatments to use against SARS-CoV-2 infection [24].

\section{Remdesivir}

Remdesivir (GS-5734) is an analogue of adenosine triphosphate [25]. It interferes with the production of viral RNA (genetic material), preventing the virus from multiplying inside cells. This may help patients heal faster [26]. In literature, firstly in 2016, it was identified as a potential treatment for Ebola virus. In 2017, studies showed its activity for the coronavirus family [25].

Remdesivir is being investigated as a potential therapy for SaRS-coV-2 which is responsible for COVID-19. FDA allowed emergency usage of remdesivir in the COVID-19 pandemic situation on May 1st, 2020 [27]. 
A study showed that remdesivir can shorten recovery and reduce mortality in COVID-19; but also, can cause acute respiratory failure [28]. The most common adverse events are diarrhea, rash, renal impairment, increased hepatic enzymes and hypotension [29].

In another study conducted for remdesivir on a compassionate-use basis to patients hospitalized with COVID-19, the most common serious adverse events that are observed were multiple-organ-dysfunction syndrome, septic shock, acute kidney injury, and hypotension. These adverse events were reported for patients who were receiving invasive ventilation at baseline. Additionally, hypernatremia, deep vein thrombosis, pneumothorax, hematuria, pyrexia, renal impairment, rash, diarrhea, acute respiratory distress syndrome and atrial fibrillation were reported $[29,30]$.

Before considering remdesivir, it is important to pay attention to renal events, pregnancy, hypersensitivity reactions, and concomitant vasopressor usage [30].

\section{Chloroquine/hydroxychloroquine}

Chloroquine and hydroxychloroquine are anti-malarial and autoimmune disease drugs. Studies show that these anti-malaria drugs in test tubes can block the coronaviruses from invading cells. Scientists initially theorized that the anti-inflammatory effect of drugs that make them beneficial against arthritis could reduce swelling in the lungs that can make it difficult for people with COVID-19 to breathe [31].

The adverse events of chloroquine and hydroxychloroquine include GI system disorders such as vomiting, diarrhea, cardiac arrhythmia. Long term exposure to these drugs can cause severe side effects like retinopathy, bull's eye maculopathy, diametric defects in the retina and cardiomyopathy [29].

It was reported in an interim guidance of WHO that chloroquine and hydroxychloroquine with or without azithromycin can cause QT prolongation and taking together can increase the risk of cardiotoxicity [32].

In Turkey, myasthenic syndrome was seen in a 47-year-old male, caused by hydroxychloroquine usage for COVID-19 prophylaxis [27]. Also, another case was reported for prolongation of QT interval in a 28-year-old male patient due to hydroxychloroquine overdose used in COVID-19 treatment [33].

\section{Lopinavir plus ritonavir}

Lopinavir and ritonavir combination is commonly used for Human Immunodeficiency Virus (HIV). In 2003, after the SARS outbreak, lopinavir was accepted as a potential treatment [34]. Lopinavir and ritonavir are in the class of drugs known as HIV protease inhibitors. Ritonavir helps increase the amount of lopinavir in the body, so these two drugs are taken together to have a greater effect [35].

Identified serious adverse effects of lopinavir and ritonavir therapy include gastrointestinal distress, QT prolongation, drug-drug interactions (ritonavir), anemia, leukopenia, neutropenia, hyperglycemia, hypertriglyceridemia and kidney failure [36].

Lopinavir/ritonavir and hydroxychloroquine sulfate both prolong the QT interval. Therefore, it is recommended to avoid the combination of these two drugs [37].

A study showed that for patients with severe COVID-19 infection, lopinavir and ritonavir had no benefit, therefore several gastrointestinal adverse events occurred as diarrhea, vomiting, nausea [29].

In a clinical trial where patients treated with azithromycin, chloroquine, lopinavir, there were $14.2 \%$ side effects for lopinavir, $1.6 \%$ of chloroquine. Those include sudden or aborted deaths (6.1\%), among which $4(3.0 \%)$ of sudden or unexplained deaths, cardiac arrests (3.3\%), ventricular arrhythmias $(68.7 \%)$, prolonged QTs (15.3\%), severe conduction disorders (3.8\%) and other cardiac troubles, supraventricular arrhythmias, 1 chest pain and 1 case of suffocating and palpitation sensations in an asthmatic patient [38].

Another study showed that the ADR rate is $37.8 \%$ in the patients under treatment of lopinavir/ ritonavir and umifenovir. Those ADRs were drug-induced gastrointestinal disorders and liver system disorders [39].

In addition to all these drug therapies, convalescent plasma or immunoglobulins from recovered individuals have been tried and used in the treatment of SARS, Ebola infection, and H1N1 influenza. These treatments work to suppress viremia, enhance humoral response, and accelerate viral clearance from the infected cell [40]. During the pandemic, FDA has issued an Emergency Use Permit for COVID-19 convalescent plasma for the treatment of hospital- 
ized COVID-19 patients. However, according to the COVID-19 Treatment Guidelines Panel conducted by the National Institutes of Health (NIH); because there is insufficient data to recommend for or against the use of convalescent plasma in the treatment of COVID-19, convalescent plasma should not be considered as standard care in the treatment of COVID-19 patients. As a result, prospective, well-controlled, sufficiently robust randomized studies are needed to determine whether convalescent plasma is effective and safe in treating patients with COVID-19 [41].

\section{Azithromycin}

Azithromycin is a broad-spectrum macrolide antibiotic with a long half-life and a high degree of tissue penetration. It can be used in the treatment of respiratory, enteric and genitourinary infections [27].

A study was funded by the French government in March 2020, in order to investigate the treatment of COVID-19 with the combination of azithromycin and the malaria drug hydroxychloroquine, and it was seen that all patients receiving the combination were virologically treated within 6 days after treatment [42].

Macrolides inhibit protein synthesis and translation which stop bacterial growth, thereby treat bacterial infections. Azithromycin is used in chronic respiratory inflammatory diseases as it has additional immunomodulatory effects.

The most common side effects related to treatment are gastrointestinal system related complaints such as diarrhea, nausea and abdominal cramps. Rarely, clinically significant elevations in transaminases, cholestatic hepatitis, jaundice and liver failure may be seen [27].

A study showed that $600 \mathrm{mg}$ hydroxychloroquine daily plus azithromycin caused several adverse effects such as insomnia, headaches, skin reactions, digestive upset with nausea, vomiting and diarrhea, blurred vision, local pain and it may also lead to increased anxiety and mental distress [43].

\section{Favipiravir}

Favipiravir, also known as T-705, is a new antiviral drug that selectively and strongly inhibits the RNAdependent RNA polymerase (RdRP) of influenza and many other RNA viruses. It was developed as an an- ti-influenza drug effective against severe infections caused by high viral load and was approved in Japan for the treatment of influenza infection [44].

Favipiravir has strong antiviral activity against all influenza viruses. It has been reported to inhibit the replication of different RNA viruses, including neurovirus, flavivirus, alphavirus, and hantavirus in vitro and animal models. Because of the different mechanism of action of favipiravir, it is possible to combine it with other antiviral treatments. Accelerated clinical improvement was observed with favipiravir-oseltamivir combination therapy compared to oseltamivir monotherapy in the severe influenza outbreak in China [45].

Favipiravir appears to be a promising agent, not only in the treatment of influenza but also in the treatment of various RNA virus infections and is positioned as a broad-spectrum anti-RNA drug. It is recommended to take Favipiravir tablet orally in the fasted state.

Therefore, oral loading is required to obtain sufficient blood levels. In people with liver dysfunction, blood concentration should be monitored, and dosage should be adjusted [46].

Although it is generally well-tolerated, gastrointestinal system related complaints such as diarrhea, nausea, increased gas, increase in serum uric acid, transaminase (ALT, AST, ALP) and total bilirubin levels, and a decrease in neutrophil levels can be observed [47]. Favipiravir carries a risk of teratogenicity and embryotoxicity [27]. Therefore, its use in pregnancy is contraindicated. Contraception is recommended for women of childbearing age up to 7 days after the end of treatment [47].

In a study with COVID-19 infected patients, it is shown that favipiravir has better treatment effects on disease progression, viral clearance. It relieves pyrexia and cough. Adverse effects caused by Favipiravir are mild and manageable [48].

\section{The Changes in Pharmacovigilance in Turkey}

Although at the beginning of the national lockdown, the pandemic had started to affect all stakeholders in the healthcare industry, Turkish Medicines and Medical Devices Agency (TITCK) was one of the firsts to assess the impact and take necessary actions. Many updates to daily practices were published. 
With these new announcements, Pharmacovigilance affiliate was able to continue fulfilling the requirements while staying compliant.

TITCK published the measures taken in this period immediately, drew attention to the importance of the issue. TITCK announced an official letter containing the recommendation of the Scientific Committee for organizations with international participation in order to prevent the spread of COVID-19 to the country on the 12th of March. In this announcement, it was stated that the measures shared by WHO were complied with and the necessary measures were taken.

In order to contribute adverse reporting in Turkey, COVID-19 specific adverse reaction forms (Adverse Reaction Reporting Form for COVID-19 Treatment) and follow up forms has been published by TITTCK $[49,50]$. These forms are made available to consumers and healthcare professional. With these specific forms, more details are requested from the reporter such as COVID-19 specific treatment and product, dosage information, exposure dates, concomitant products, COVID-19 diagnosis date, adverse event and its start date, other diseases and allergies, comments from the reporter. With this form, reporting is encouraged, and awareness is increased.

Active ingredients of drugs that can be used in the treatment of COVID-19 are included in the "TITTCK Off Label Drug List That Can Be Used Without Additional Approval" published on TITCK's website on the 24th of March. These substances are lopinavir+ritonavir, hydroxychloroquine sulfate, chloroquine phosphate, and tocilizumab. Suspect drugs in the form are oseltamivir, hydroxychloroquine, azithromycin, favipiravir, lopinavir+ritonavir and tocilizumab.

Many announcements regarding specific subjects, including but not limited to, supply of medication under limited distribution including medication prescribed with Safety Monitoring Form, supply of medication without fresh prescription for chronic diseases, "New Manufacturer Adverse Event Report".

Some steps in the medication supply process for patients with chronic diseases and patients with a Medical Board Report were reduced to minimize the risk of infection: The period of validity was extended at first to 30 days and eventually to 90 days $[51,53]$. This way, the pharmacist became able to provide the amount of product that would be corresponding to 90-day treatment, and patients were able to receive their treatment in a timely manner. Many steps such as prescription renewal that required the patient to go to the clinic were eliminated. Therefore, the importance of pharmacists increased as pharmacists became the first pillar of communication for essential warnings and information to patients.

Additionally, guidance regarding COVID-19 patients' treatment was published. The treatment options were listed in "List of Off-Label Medicines Which May Be Used Without Supplemental Authorization of TITCK" to facilitate the Current COVID-19 Patient Management and Treatment.

\section{Conclusions}

The COVID-19 pandemic represents the largest global public health crisis of this century. To date, drug therapy has been the only available approach for a rapid response to the pandemic. As mentioned above, some drugs have shown some activity against COVID-19. On the other hand, although these drug therapies have been tested on many patients and seen as promising therapies, for now, no solid or convincing data has yet been published on the effectiveness of these drugs in COVID-19. It should also be noted that as with all drugs, pharmacovigilance activities carry great importance in the pandemic.

Effective treatments and vaccines are being developed for COVID-19, which has spread rapidly around the world and endangers human health, but as with all drugs, pharmacovigilance activities carry great importance in this process.

In order to analyze the risks of adverse reactions, it is necessary to collect the details of all events. The relationship between the application of the drug and observing an adverse event is also another criteria in the evaluation of the risk. Healthcare providers need to ensure the collection of accurate data from adverse event reports [54].

In any case, healthcare providers, especially pharmacovigilance experts, need to be vigilant about all the risks related to drug safety during the pandemic and strengthen adverse event reporting systems and minimize the risks of the novel therapies.

Besides the monitoring of adverse reactions of drugs used in the COVID-19 treatment, we need to be alert 
about hidden effects of medicinal products such as poisoning through inhalation of disinfectants, cardiac problems associated with overdose chloroquine intake and overdosing of multivitamins [55].

Suspected adverse event reports for these novel therapies have been already submitted to the global database of ICSRs [56]. However, challenges in pharmacovigilance such as lack of awareness in reporting adverse reactions become even more crucial with the current pandemic, during which it is more difficult to collect adverse reaction data due to the lack of physical contact, travel restrictions and quarantine. Follow-ups on the cases can be harder due to the same reasons.

\section{Acknowledgement}

The authors take this opportunity to thank to all of the healthcare workers for critical effort during the COVID-19 pandemic..

\section{Conflict of Interest}

None

\section{References}

1. “Genel Bilgiler, Epidemiyoloji ve Tan1," 2020. [Online]. Available: https://covid19.saglik.gov.tr/TR-66337/genel-bilgilerepidemiyoloji-ve-tani.html\#.

2. A. L. YAĞCI İ., Sarikaya S., Ayhan F. F. , Bahsi A., Kaya B. B. , ERHAN B. , Ahi E. D. , Okan S., Ozkan Y., Korkmaz M. D. , Yaksi E., Kabayel D. D. , Ozdemir H., Kayalar G., Celik C., Kesiktas F. N. , Yagci H. C., "The effects of COVID-19 on Physical Medicine and Rehabilitation in Turkey in the first month of pandemic," TURKISH J. Phys. Med. Rehabil., vol. 66, pp. 244-251, [Online]. Available: http://www.ftrdergisi. com/uploads/pdf/pdf_4214.pdf.

3. D.-G. Ahn et al., "Current Status of Epidemiology, Diagnosis, Therapeutics, and Vaccines for Novel Coronavirus Disease 2019 (COVID-19)," J. Microbiol. Biotechnol., vol. 30, pp. 313-324, 2020, doi: 10.4014/jmb.2003.03011.

4. M. Koska and H. Süslü, "Cutaneous Findings of COVID-19: A Review of the Literature," J. Turkish Acad. Dermatology, vol. 14, pp. 30-43, Jun. 2020, doi: 10.4274/jtad.galenos.2020.36855.

5. P. Yamoah, T. M. Alalbila, V. Bangalee, and F. Oosthuizen, "Coronavirus Disease 2019 (COVID-19) Spread and Pharmacovigilance Implications: Expert Opinion,” Drug Inf. J., pp.
1-4, May 2020, doi: 10.1007/s43441-020-00158-8.

6. M. Uddin et al., "SARS-CoV-2/COVID-19: Viral Genomics, Epidemiology, Vaccines, and Therapeutic Interventions," Viruses, vol. 12, no. 5, p. 526, May 2020, doi: 10.3390/ v12050526

7. Z. Y. Zu et al., "Coronavirus Disease 2019 (COVID-19): A Perspective from China," Radiology, vol. 296, no. 2, pp. E15E25, Feb. 2020, doi: 10.1148/radiol.2020200490.

8. H. A. Rothan and S. N. Byrareddy, "The epidemiology and pathogenesis of coronavirus disease (COVID-19) outbreak," J. Autoimmun., vol. 109, p. 102433, 2020, doi: https://doi. org/10.1016/j.jaut.2020.102433.

9. “Coronavirus Resource Center." [Online]. Available: https:// coronavirus.jhu.edu/.

10. "Coronavirus Resource Center: Turkey." [Online]. Available: https://coronavirus.jhu.edu/region/turkey.

11. "'Solidarity' clinical trial for COVID-19 treatments." [Online]. Available: https://www.who.int/emergencies/diseases/novel-coronavirus-2019/global-research-on-novel-coronavirus2019-ncov/solidarity-clinical-trial-for-covid-19-treatments.

12. "COVID-19: latest updates." [Online]. Available: https://www. ema.europa.eu/en/human-regulatory/overview/public-healththreats/coronavirus-disease-covid-19/covid-19-whats-new.

13. "Coronavirus Disease 2019 (COVID-19)." [Online]. Available: https://www.fda.gov/emergency-preparedness-andresponse/counterterrorism-and-emerging-threats/coronavirusdisease-2019-covid-19.

14. "COVID-19 - Informations réglementaires." [Online]. Available: https://www.ansm.sante.fr/Dossiers/COVID-19/ COVID-19-Informations-reglementaires/(offset)/7.

15. "Pharmacovigilance et addictovigilance dans le contexte du COVID-19 : une surveillance renforcée." [Online]. Available: https://www.ansm.sante.fr/Declarer-un-effet-indesirable/ Systemes-de-vigilances-de-1-Agence/COVID-19-Dispositifrenforce-de-Pharmacovigilance-et-d-Addictovigilance/(offset) $/ 0$.

16. "DHSC and PHE statement on coronavirus," 2020. [Online]. Available: https://www.gov.uk/government/news/dhsc-andphe-statement-on-coronavirus.

17. "MHRA regulatory flexibilities resulting from coronavirus (COVID-19)," 2020. [Online]. Available: https://www.gov. uk/guidance/mhra-regulatory-flexibilities-resulting-fromcoronavirus-covid-19\#pharmacovigilance.

18. "COVID-19 Terms and MedDRA." [Online]. Available: https://www.meddra.org/COVID-19-terms-and-MedDRA.

19. M. Iyer et al., "COVID-19: an update on diagnostic and therapeutic approaches,” BMB Rep., vol. 53, no. 4, pp. 191-205, Apr. 2020, doi: 10.5483/BMBRep.2020.53.4.080. 
20. "The Drug Development Process." [Online]. Available: https://www.fda.gov/patients/learn-about-drug-and-deviceapprovals/drug-development-process.

21. "Coronavirus (COVID-19) Update: FDA Continues to Facilitate Development of Treatments," 2020. [Online]. Available: https://www.fda.gov/news-events/press-announcements/ coronavirus-covid-19-update-fda-continues-facilitatedevelopment-treatments.

22. "Call to pool research resources into large multi-centre, multiarm clinical trials to generate sound evidence on COVID-19 treatments," 2020. [Online]. Available: https://www.ema. europa.eu/en/news/call-pool-research-resources-large-multicentre-multi-arm-clinical-trials-generate-sound-evidence.

23. V. H.-L. Regás, M. T. D. Culla, and R. L. Bellfill, "Adverse reactions of drugs specifically used for treatment of SARSCoV-2 infection,” Med. Clínica (English Ed., 2020.

24. "EU Risk Management Plan for Remdesivir." [Online]. Available: https://www.ema.europa.eu/en/documents/rmp/vekluryepar-risk-management-plan_en.pdf.

25. T. P. Sheahan et al., "Broad-spectrum antiviral GS-5734 inhibits both epidemic and zoonotic coronaviruses," Sci. Transl. Med., vol. 9, no. 396, 2017.

26. "Veklury (remdesivir): An overview of Veklury and why it is authorised in the EU," 2020. [Online]. Available: https://www. ema.europa.eu/en/documents/overview/veklury-epar-medicine-overview_en.pdf.

27. S. Z. Tatlı, G. Çakar, B. Çolak, and E. T. Ö. Kızıl, "COVID-19 pandemisinde psikofarmakolojik tedavi," Klin. Psikiyatr. Derg., p. 23, 2020.

28. S. A. Doggrell, "Remdesivir, a remedy or a ripple in severe COVID-19?," Expert Opin. Investig. Drugs, vol. 29, no. 11, pp. 1195-1198, Nov. 2020, doi: 10.1080/13543784.2020.1821645.

29. B. Gasser and R. A. R. Uscategui, "POTENTIAL THERAPIES FOR TREATMENT OF COVID-19," Rev. Ciência Veterinária e Saúde Pública, vol. 7, no. 1 SE-Artigos Originais, Aug. 2020, doi: 10.4025/revcivet.v7i1.55502.

30. "Summary on compassionate use: Remdesivir," 2020. [Online]. Available: https://www.ema.europa.eu/en/documents/ other/summary-compassionate-use-remdesivir-gilead_en.pdf.

31. T. Carr, "Doctors on the Front Lines Are Testing New Therapies to Treat COVID-19," 2020. [Online]. Available: https:// www.consumerreports.org/medical-treatments-procedures/ new-therapies-to-treat-covid-19/.

32. "Clinical Management of COVID-19," 2020. [Online]. Available: https://www.who.int/publications/i/item/clinicalmanagement-of-covid-19.

33. G. Aksel, M. M. Islam, T. Aslan, and S. E. Eroglu, "Prolongation of QT interval due to hydroxychloroquine overdose used in COVID-19 treatment," Turkish J. Emerg. Med., vol. 20, no. 3, pp. 149-151, Jul. 2020, doi: 10.4103/2452-2473.290063.

34. E. Mahase, "Coronavirus: covid-19 has killed more people than SARS and MERS combined, despite lower case fatality rate," BMJ, vol. 368, 2020, doi: 10.1136/bmj.m641.

35. "Lopinavir and Ritonavir: MedlinePlus Drug Information." [Online]. Available: https://medlineplus.gov/druginfo/meds/ a602015.html.

36. N. Mehta, M. Mazer-Amirshahi, N. Alkindi, and A. Pourmand, "Pharmacotherapy in COVID-19; A narrative review for emergency providers," Am. J. Emerg. Med., vol. 38, no. 7, pp. 1488-1493, Jul. 2020, doi: 10.1016/j.ajem.2020.04.035.

37. "A randomized, controlled open-label trial to evaluate the efficacy and safety of lopinavir-ritonavir in hospitalized patients with novel coronavirus pneumonia (COVID-19)." [Online]. Available: http://www.chictr.org.cn/showprojen. aspx?proj $=48684$.

38. A. Gérard et al., “'Off-label' use of hydroxychloroquine, azithromycin, lopinavir-ritonavir and chloroquine in COVID-19: A survey of cardiac adverse drug reactions by the French Network of Pharmacovigilance Centers," Therapies, vol. 75, no. 4, pp. 371-379, 2020, doi: https://doi.org/10.1016/j.therap.2020.05.002.

39. J. Sun et al., "Incidence of Adverse Drug Reactions in COVID-19 Patients in China: An Active Monitoring Study by Hospital Pharmacovigilance System," Clin. Pharmacol. Ther., vol. 108, no. 4, pp. 791-797, Oct. 2020, doi: 10.1002/cpt.1866.

40. K. Pennington and E. Carmona, "Currently Available and Emerging Therapies for COVID-19." [Online]. Available: https://www.chestnet.org/Guidelines-and-Resources/COVID-19/Currently-Available-and-Emerging-Therapies-forCOVID-19.

41. "What's New in the Guidelines." [Online]. Available: https:// www.covid19treatmentguidelines.nih.gov/whats-new/.

42. P. Gautret et al., "Hydroxychloroquine and azithromycin as a treatment of COVID-19: results of an open-label nonrandomized clinical trial,” Int. J. Antimicrob. Agents, vol. 56, no. 1, p. 105949, 2020, doi: https://doi.org/10.1016/j.ijantimicag.2020.105949

43. I. Nessaibia, D. Siciliano, and A. Tahraoui, "Why nobody discusses the adverse psychiatric effects of chloroquine in case it might become the future treatment against COVID-19?," Int. J. Health Plann. Manage., vol. n/a, no. n/a, Sep. 2020, doi: https://doi.org/10.1002/hpm.3057.

44. Y. Furuta, B. B. Gowen, K. Takahashi, K. Shiraki, D. F. Smee, and D. L. Barnard, "Favipiravir (T-705), a novel viral RNA polymerase inhibitor," Antiviral Res., vol. 100, no. 2, pp. 446454, Nov. 2013, doi: 10.1016/j.antiviral.2013.09.015. 
45. B. Wang, Y., Fan, G., Salam, A., Horby, P., Hayden, F. G., Chen, C., Pan, J., Zheng, J., Lu, B., Guo, L., Wang, C., \& Cao, "Comparative Effectiveness of Combined Favipiravir and Oseltamivir Therapy Versus Oseltamivir Monotherapy in Critically Ill Patients With Influenza Virus Infection,’ J. Infect. Dis., vol. 221, no. 10, pp. 1688-1698, 2020, doi: https://doi. org/10.1093/infdis/jiz656.

46. V. Madelain et al., "Ebola Virus Infection: Review of the Pharmacokinetic and Pharmacodynamic Properties of Drugs Considered for Testing in Human Efficacy Trials," Clin. Pharmacokinet., vol. 55, no. 8, pp. 907-923, Aug. 2016, doi: 10.1007/ s40262-015-0364-1.

47. "Faviravir: Favipiravir Leaflet." [Online]. Available: https:// www.aci-bd.com/Brand/Faviravir.pdf.

48. M. Nasir, R. Perveen, S. Sk, K. Talha, and I. Ma, "Systematic Review on Repurposing Use of Favipiravir Against SARSCoV-2," Mymensingh Med. J., vol. 29, pp. 747-754, Sep. 2020.

49. "COVID-19 Tedavisine Yönelik Advers Reaksiyon Bildirim Formu," 2020. [Online]. Available: https://titck.gov.tr/ storage/Archive/2020/contentFile/Covid-19 Advers Reaksiyon Bildirim Formu-web yayın_1fea7671-1dba-4e4a-9515e623be819d6e.pdf.

50. "COVID-19 Advers Reaksiyon (İstenmeyen Etki) Takip Formu," 2020. [Online]. Available: https://titck.gov.tr/storage/Archive/2020/contentFile/Covid-19 Advers Reaksiyon Takip Formuweb yayın_83840ddb-bbe4-4108-a0c4-58dac7b51de0.pdf.

51. “TITCK Duyuru 3774,” 2020. [Online]. Available: https:// www.titck.gov.tr/duyuru/3774.

52. "İlaç Güvenlik İzlem Formu ile Kullanılan ve Kısıtlı Dağıtımda Olan İlaçların Temini,” 2020. [Online]. Available: https://www. titck.gov.tr/duyuru/ilac-guvenlik-izlem-formu-ile-kullanilanve-kisitli-dagitimda-olan-ilaclarin-01042020114742.

53. “İlaç Güvenlik İzlem Formu ile Kullanılan ve Kısıtlı Dağıtımda Olan İlaçların Temini Hakkında Duyuru,” 2020 [Online]. Available: https://www.titck.gov.tr/duyuru/ilacguvenlik-izlem-formu-ile-kullanilan-ve-kisitli-dagitimdaolan-ilaclarin-temini-hakkinda-duyuru-06072020172105.

54. "PHARMACOVIGILANCE IN THE AGE OF COVID-19," 2020. [Online]. Available: https://www.uppsalareports.org/ articles/pharmacovigilance-in-the-age-of-covid-19/.

55. C. Ogar, W. Mathenge, C. Khaemba, and H. Ndagije, "The challenging times and opportunities for pharmacovigilance in Africa during the COVID-19 pandemic," Drugs Ther. Perspect. Ration. drug Sel. use, pp. 1-4, May 2020, doi: 10.1007/ s40267-020-00748-4.

56. R. E. Chandler, D. McCarthy, J.-C. Delumeau, and M. Harrison-Woolrych, "The Role of Pharmacovigilance and ISoP Du- ring the Global COVID-19 Pandemic," Drug Saf., vol. 43, no. 6, pp. 511-512, Jun. 2020, doi: 10.1007/s40264-020-00941-4. 